\title{
The Effect of Audit Tenure, Audit Delay, Company Growth, Profitability, Leverage, and Financial Difficulties on Acceptance of Going Concern Audit Opinions
}

\author{
Wahyu Manuhara Putra ${ }^{1, *}$ Rita Purnamawati ${ }^{1}$
}

\author{
${ }^{1}$ Universitas Muhammadiyah Yogyakarta, Indonesia \\ *Corresponding author.Email: wahyu_m@umy.ac.id
}

\begin{abstract}
This study aims to analyze the influence of audit tenure, audit delay, corporate growth, profitability, leverage, and financial distress toward acceptance of going concern audit opinion. The research used manufacturing companies listed on the Indonesia Stock Exchange in 2015-2017 and obtained samples of 34 companies and 102 data to be observed for three years of the research period. This study utilized the statistical analysis technique of logistic regression. The results suggested that the variables of audit tenure, audit delay, corporate growth, and financial distress had no significant effect on the acceptance of going concern audit opinion. Instead, profitability and leverage variables significantly affected the acceptance of going concern audit opinion.
\end{abstract}

Keywords: Audit tenure, audit delay, corporate growth, profitability, leverage, financial distress, going concern audit opinion.

\section{INTRODUCTION}

A going concern audit opinion is an opinion that expresses doubt about the company's business sustainability, which means that the company's survival is predicted not to survive. Meanwhile, the non-going concern audit opinion indicates that the company is predicted to continue its business for the following years. The party responsible for the company's survival is the management (Azhar and Satriawan [1]). For the stakeholders, especially investors, the company's going concern is essential (Setiawan and Suryono [2]). Investors can assess a company's ability to continue its business by looking at the audit opinion. The issuance of a going concern audit opinion by the auditor will significantly impact the company because all parties related to the company will make decisions based on that opinion.

The magnitude of the audit opinion's impact shows that the auditor has a vital role in the relationship between company management and other stakeholders. It is where the auditor's role is needed. As an independent and trusted party, the auditor must be able to fulfill its function as a guarantor of the financial statements' correctness delivered by the agent to the principal. There is a possibility that the auditor makes mistakes (audit failures) in providing a going concern opinion (Mayangsari [3]), and it negatively impacted many parties. The inadequate basis for the auditor to give a going concern audit opinion or not and the influence of other factors, such as self-fulfilling prophecy, make this research necessary. According to Kleinman and Anandarajan [4], auditors can identify the company's going concern problem earlier, but several cases prove that not all auditors can do that.

The going concern problem is complex. According to Praptitorini and Januarti [5], doubts about the company's going concern opinion will continue to exist, so that the factors that influence it need to be studied. Besides, due to fluctuating economic conditions, the consistency level must always be measured. The goal is that the going concern status can be predicted under any circumstances. Research on the factors that influence the acceptance of going concern audit opinion is still not entirely consistent. This research is a compilation of Syahputra and Yahya [6], Syarifah and Kurnia [7], and Lie, Wardani and Pikir [8]. There are six factors to be tested: audit 
tenure, audit delay, growth, profitability, leverage, and the company's financial distress.

Until now, both theoretically and practically, the decision to determine the company's going concern status is still quite difficult. One of the reasons is because the criteria for determining opinion giving are not sufficient. Therefore, this study's purpose is to prove that audit tenure, audit delay, company growth, profitability, leverage, and financial distress affect the acceptance of going concern audit opinion.

\section{PREVIEW RESEARCH}

\section{Characteristic of variables}

Agency theory assumes that both the agent and the principal have personal interests and act according to those interests, so the possibility arises that the agent does not provide correct information about the company to the principal (Dewayanto [9]). This condition is known as information asymmetry, and to reduce this information asymmetry, it is necessary to have an independent party that guarantees the financial statements' fairness delivered by the agent to the principal, namely the independent auditor (Wahyuni and Fitriany [10]). If the auditor doubts the company's ability to maintain its survival, the auditor is obliged to express these doubts by providing a going concern audit opinion (Solikhah, [11]).

Based on the audit report, the auditor may express his opinion or, if circumstances require, give a disclaimer of opinion. Audit opinion may vary according to the facts found during the audit process. There is also a term modified audit opinion, namely going concern audit opinion and non-going concern audit opinion. Rahayu [12] explains two things in interpreting going concern: a concept and an audit opinion. According to the concept, going concern is the company's ability to maintain its business continuity, while the audit opinion means that the auditor doubts the company's ability to continue its business in the future. Going concern is always associated with management's ability to manage the company to survive (Putra and Suryandari, 2010) and to continue to realize projects, carry out responsibilities, and various activities for a long time (Suwardjono [13]).

The company avoids going concern audit opinion as much as possible because it has quite a massive impact, such as a decline in stock prices, doubts and distrust of stakeholders in management, and difficulties in obtaining loan capital to improve the situation (Krissindiastuti and Rasmini, [14]). On the other hand, if the opinion is not proven (the company can maintain its business continuity), there is a high probability that the auditor will face the risk of losing the client (Carcello, Vanstraelen, and Willenborg [15]).

Audit tenure is the length of cooperation between the audit firm and the same client. Government regulations state that the provision of financial statement audit services for an entity is carried out by the audit firm for a maximum of five years continuously and an external auditor for a maximum of three years. It is feared that the lengthy engagement between the auditor and the auditee could reduce the auditor's independent attitude. This limitation is reinforced by administrative sanctions in the form of a written warning or license suspension.

Audit delay is the length of time the auditor takes to complete the audit. According to Ibrahim and Raharja [16], audit delay is calculated from the date of the financial statements to the date the independent auditor's report is issued, indicating the auditor's length of time completes the audit. The audit delay regulation in Indonesia states that the maximum time limit for a company submit annual reports is no later than the end of the fourth month after the financial year ends. It means that the auditors have 120 days to complete their audit assignments. Audit delay can affect the timeliness of releasing accounting information (Ashton, Willingham, and Elliot, [17]). The timeliness value of the information lies in the relevance of the information to users' needs. The more on time, the information will be more relevant and useful for reliable decision making (Ratmono and Septiana, [18]).

A company that is growing is a company that can generate significant profits through operating activities every year. The higher the sales growth ratio, the less likely the auditor will provide a going concern audit opinion to the auditee (Krissindiastuti and Rasmini, [14]). Conversely, the company will have more potential to receive a going concern audit opinion if its sales continue to decline because there is no source of funds for the company to continue operating. The negative profit growth exposes the company to bankruptcy.

Companies with high profitability mean they have a promising future because they can continue to generate profits from their operations. The higher the company's profitability, the less likely it is to get a going concern audit opinion because high profitability signifies that the company will have sufficient funds to continue operating.

The leverage's purpose is to use assets or funds with fixed costs and increase and maximize the company's wealth. The higher the leverage ratio level, the greater the receipt of funds used to finance debt so that there are fewer funds for operational activities; thus, it raises doubts about maintaining its business viability in the future. It can explain that it is likely that the auditor will provide a going concern audit opinion.

In 1968, Altman made a Z-Score analysis model, an equation model to predict a company's future condition, whether in good condition or bankrupt. The Z-score prediction model can be an effective tool for auditors in considering their opinions. Several studies have revealed that auditors tend to give the auditee going concern 
qualifications if the auditee is experiencing a significant financial difficulty level (Nogler [19]).

\section{Hypothesis Derivation}

\section{The Effect of Audit Tenure on the Acceptance of} Going Concern Audit Opinions

According to Junaidi and Hartono [20], it is feared that the long-standing relationship between the audit firm and the company could affect audit firm independence. The closeness of the relationship between company management and auditors can threaten auditor independence (Carey and Simnett [21]). The lower the independence level, the lower the integrity level of the audit opinion. There is a possibility that the auditor does not disclose problems that occur at the auditee to protect the auditee's interests.

Putri and Fettry [22] found that audit tenure did not affect the acceptance of a company's going concern audit opinion. Professional ethics demands for auditors to always work professionally without being influenced by their closeness to clients due to long working time. Besides, Solikhah [11] also proved that the going concern audit opinion in Indonesia was not influenced by audit tenure. The time limitation between the auditor and the company through a government regulation did not make the auditor afraid of losing the contract if he issued a going concern audit opinion.

However, research by Junaidi and Hartono [20] and Muttaqin and Sudarno [23] discovered that the acceptance of going-concern audit opinion was influenced by the audit tenure. The length of the engagement between the audit firm and the company is one of the determinants of whether or not a going concern audit opinion is accepted. Nursasi and Maria [24] also found the same result; their study stated empirical evidence that auditor independence could be impaired by the length of the engagement between the auditor and his client. Besides, Krissindiastuti and Rasmini [14] and Syahputra and Yahya [6] also uncovered evidence that audit tenure negatively affected the going concern audit opinion acceptance. The longer the audit firm and auditee's engagement, the lower the auditee's probability of receiving a going concern audit opinion from the auditor. Based on the above, the hypothesis is:

H1: Audit tenure has a negative effect on the going concern audit opinion acceptance.

\section{The Effect of Audit Delay on the Acceptance of Going Concern Audit Opinions}

Audit delay affects the level of relevance and usefulness of financial information, which decreases with the more prolonged the audit delay. It will affect stakeholder decisions' accuracy, influencing the company's investment decisions (Septiana [25]). Research by Agustina and Zulaikha [26] concluded that audit delay had no significant effect on the going concern audit opinion acceptance. The auditor uses the audit process's length to gather sufficient evidence and evaluate the management plan's effectiveness to improve the company's finances. The same results were also found in research from Syahputra and Yahya [6] that the audit's length is not yet a sign that the auditor will issue a going concern audit opinion because the auditor takes a long time to obtain audit evidence.

On the other hand, Januarti and Fitrianasari [27] proved that audit delay positively affected going concern audit opinion acceptance. Prolonged audit activity can be a sign that the auditee has severe problems in its business. Besides, Astuti and Darsono [28] and Mariani [29] concluded that the longer the time for completing the audit task, the greater the auditor's doubts regarding the possibility of the auditee's going concern. The auditor should do more testing and judgment before giving an audit opinion. It means that the auditee has a greater probability of receiving a going concern audit opinion and the longer the audit delay. Therefore, in this study, the researcher formulated the following hypotheses:

H2: Audit delay has a positive effect on the going concern audit opinion acceptance.

\section{The Effect of Company Growth on the Acceptance of Going Concern Audit Opinions}

Research by Sulistya and Sukartha [30], Setiawan and Suryono [2], and Ariesetiawan and Rahayu [31] exposed that company growth did not affect going concern audit opinion acceptance. The auditee may still get a going concern audit opinion even though the company is growing positively. This result is further supported by the research of Aprinia and Hermanto [32], Putra, Anwar, and Nur [33], Mustika [34], and Syarifah and Kurnia [7]. Syarifah and Kurnia's research measured company growth with sales growth proved that there was no guarantee that a company with an increase in net sales would also experience an increase in its net profit.

However, research by Kartika [35] and Kristiana [36] proved a negative influence of company growth on the going concern audit opinion acceptance. Ginting and Suryana [37] and Sari and Wahyuni [38] deduced that positive sales would make the company's value also continue to grow to maintain its survival without worrying about the company's going concern.

Nursasi and Maria [24] and Krissindiastuti and Rasmini [14] got the results of the company growth's negative influence on the going concern audit opinion acceptance. The company's sales growth shows its strength in the industry and indicates its ability to maintain its business continuity. Profitable growth makes auditors have no doubts about the auditee's business sustainability. If the auditee's sales growth ratio is high, the auditor will be less likely to issue a going concern 
audit opinion (Istiana, [39]). Based on this, the hypothesis is:

H3: Company growth has a negative effect on the going concern audit opinion acceptance.

\section{The Effect of Profitability on the Acceptance of Going Concern Audit Opinions}

A company's ability to earn profits and the business efficiency level is usually measured using the profitability ratio (Lie, Wardani and Pikir [8]. Companies with high profitability ratios are less likely to get a going concern audit opinion because high profitability indicates that the auditee's business is going well, as found by Azhar A, Hardi, and Satriawan [1] and Pasaribu [40] that profitability did not affect going concern audit opinion acceptance. Lie, Wardani, and Pikir [8] also disclosed the same thing. Although experiencing increased profits, companies experiencing major problems will find it difficult to return things to be good again.

However, Setiawan and Suryono [2] and Ariesetiawan and Rahayu [31], and Putra and Suryanndari [41] found that profitability had a negative effect on the going concern audit opinion acceptance. They concluded that the higher the profitability, the better the company's condition, and the smaller it would accept going concern audit opinion. Aprinia and Hermanto [32] also discovered the same results. Companies that lose money (low/minus profitability) are more likely to get a going concern audit opinion.

Likewise, Pradika and Sukirno [42] revealed that profitability negatively influenced the going concern audit opinion acceptance. High profitability is a sign that the company's operational activities are going well. Operations that run well are also considered to be able to encourage the company's condition as a whole to jointly move in a positive direction so that the auditee will be able to improve the company's condition. It means that good profitability will further reduce the auditee's possibility of receiving a going concern audit opinion from the auditor. Then, the hypothesis is:

H4: Profitability has a negative effect on the going concern audit opinion acceptance

\section{The Effect of Leverage on the Acceptance of Going Concern Audit Opinions}

Leverage is a representation of the debt using in financing its operational activities. The greater the leverage ratio, the greater the company's income is used to pay off its debt; as a result, the company's revenue for operational activities will decrease. Consequently, there are doubts about the company's ability to maintain its business continuity in the future. Auditors will tend to give a going concern opinion if the company's leverage is getting bigger.
Research Setiawan and Suryono [2] proved that leverage significantly impacted the going concern audit opinion. Also, Masyitoh and Adhariani [43] stated that leverage was positively related to the acceptance of going concern audit opinion. Different results were found in Ibrahim \& Raharja's [16] research that leverage did not affect going concern audit opinion. From several previous research results, the hypothesis could be formulated:

H5: Leverage has a positive effect on the going concern audit opinion acceptance.

The Effect of Financial Difficulties on the Acceptance of Going Concern Audit Opinions

Altman and McGough [44] suggest that the primary basis for the auditor's consideration in giving an opinion is the determinant factor of going concern. Several studies have concluded that the auditor was likely to give a going concern qualification if the client company experienced financial problems. Research Syarifah and Kurnia [7] supported by Mukhtaruddin et al. [45] proved that the financial condition variable proxied by the Altman Z-Score model significantly affected giving going concern audit opinion. Ross et al. [46] stated that the company bankruptcy potential could be predicted from its financial distress level. Research by Istiana [39] and Ginting and Suryana [37] also proved that the auditor's financial condition affected the going concern audit opinion. However, these results are not supported by Rahayuningsih [47] that financial conditions did not affect because they were not significant for the disclosure of going concern audit opinion. From several previous studies, the following hypothesis could be formulated:

H6: Financial difficulties have a positive effect on the going concern audit opinion acceptance.

\section{Research Model}

The research model to test the effect of audit tenure, audit delay, company growth, profitability, leverage, and financial distress on the acceptance of going concern audit opinion is shown in the following figure:

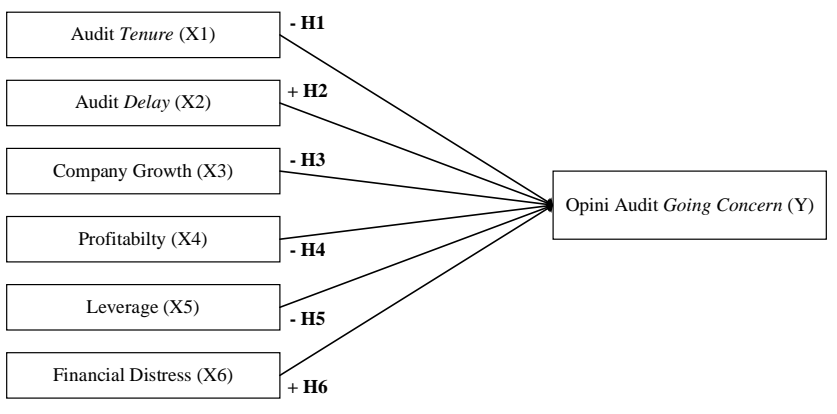

Figure 1. Research Model 


\section{RESEARCH METHOD}

This research's objects were manufacturing companies listed on the Indonesia Stock Exchange 20152017. The manufacturing sector accounts were more than a quarter of total companies so that it better described the economy and business' state, and this research's results can be generalized well. The dependent variable in this study was the going concern audit opinion. This variable was measured by a dummy. This study's independent variables were audit tenure, audit delay, company growth, profitability, leverage, and financial distress.

This study utilized logistic regression as a tool of analysis because the dependent variable was dichotomous. The regression model to test the hypothesis is:

$$
\begin{aligned}
& \mathrm{GC}=\alpha+\beta_{1} \mathrm{AT}+\beta_{2} \mathrm{AD}+\beta_{3} \mathrm{PP}+\beta_{4} \mathrm{Lev}+\beta_{5} \text { Profit }+\beta_{6} \mathrm{Distr}+\varepsilon \\
& \mathrm{GC}=\text { Going concern audit opinion } \\
& \alpha=\text { Constant } \\
& \beta=\text { Regression coefficient } \\
& \mathrm{AT}=\text { Audit tenure } \\
& \mathrm{AD}=\text { Audit delay } \\
& \mathrm{PP}=\text { Company growth } \\
& \text { Lev }=\text { Leverage } \\
& \text { Profit = Profitability } \\
& \text { Distrs }=\text { Financial difficulties }
\end{aligned}
$$

\section{RESULTS AND DISCUSSION}

\section{Statistics Result}

Table 1.

\begin{tabular}{|l|l|l|l|}
\hline \multicolumn{5}{|c|}{ Hosmer and Lemeshow Test } \\
\hline Step & Chi-square & df & Sig. \\
\hline 1 & 1.228 & 8 & .996 \\
\hline
\end{tabular}

In the Hosmer and Lemeshow test, the data is fit or feasible to explain the variables if the significance value is greater than $\alpha=5 \%(0.05)$. In table 4.4, the Hosmer and Lemeshow test's value showed a significance value of 0.996 higher than 0.05 , meaning that there was no difference between the model and the data, or it can be said that the model could be used to predict the data value.
Table 2. Determination Coefficient Test

\begin{tabular}{|c|c|c|c|}
\hline \multicolumn{3}{|c|}{ Model Summary } & \multicolumn{2}{l|}{ Cox \& Snell R } \\
Step & -2 Log likelihood & Square & Nagelkerke R Square \\
\hline 1 & $34.999^{\mathrm{a}}$ & .258 & .545 \\
\hline \multicolumn{3}{|l}{ a. Estimation terminated at iteration number 7 because parameter } \\
estimates changed by less than ,001
\end{tabular}

\begin{tabular}{|c|c|c|c|c|c|}
\hline \multicolumn{6}{|c|}{ Classification Table $^{\mathbf{a}}$} \\
\hline & \multirow{3}{*}{\multicolumn{2}{|c|}{ Observed }} & \multicolumn{3}{|c|}{ Predicted } \\
\hline & & & \multicolumn{2}{|l|}{ GC } & Percentage \\
\hline & & & 0 & 1 & Correct \\
\hline \multirow[t]{3}{*}{ Step 1} & \multirow[t]{2}{*}{ GC } & 0 & 90 & 2 & 97.8 \\
\hline & & 1 & 5 & 5 & 50.0 \\
\hline & \multicolumn{2}{|c|}{ Overall Percentage } & & & 93.1 \\
\hline \multicolumn{6}{|c|}{ a. The cut value is 500} \\
\hline
\end{tabular}

Based on table 2, it can be shown that the Nagelkerke $\mathrm{R}$ Square value was 0.545. It indicated that the independent variables of audit tenure, audit delay, company growth, profitability, leverage, and financial distress could explain the dependent variable of going concern audit opinion by $54.5 \%$. Meanwhile, the remaining $45.5 \%$ was explained by other variables outside this study.

Table 3. Matrix Classification

Table 3 displays that according to predictions, five companies received going concern audit opinions from a total of 10 companies that should receive going concern audit opinion. It could be said that the predictive power

\begin{tabular}{|c|c|c|c|c|c|c|c|c|c|}
\hline \multicolumn{10}{|c|}{ Variables in the Equation } \\
\hline & & \multirow[b]{2}{*}{$\mathrm{B}$} & \multirow[b]{2}{*}{ S.E. } & \multirow[b]{2}{*}{ Wald } & \multirow[b]{2}{*}{ df } & \multirow[b]{2}{*}{ Sig. } & \multirow[b]{2}{*}{$\operatorname{Exp}(B)$} & \multicolumn{2}{|c|}{$\begin{array}{ll}95 \% & \text { C.I.for } \\
\operatorname{EXP}(\mathrm{B}) & \\
\end{array}$} \\
\hline & & & & & & & & Lower & Upper \\
\hline \multirow[t]{7}{*}{ Step $1^{\mathrm{a}}$} & AT & $\begin{array}{l}- \\
613 \\
\end{array}$ & .517 & 1.402 & 1 & .236 & .542 & .197 & 1.494 \\
\hline & $\mathrm{AD}$ & .028 & .018 & 2.319 & 1 & .128 & 1.028 & .992 & 1.066 \\
\hline & Growth & $\begin{array}{l}- \\
.002\end{array}$ & .001 & 2.483 & 1 & .115 & .998 & .996 & 1.000 \\
\hline & ProNIAT & $\begin{array}{l}- \\
018 \\
\end{array}$ & .007 & 6.811 & 1 & .009 & .982 & .969 & .995 \\
\hline & Lev & .002 & .001 & 8.940 & 1 & .003 & 1.002 & 1.001 & 1.003 \\
\hline & DistZ & .267 & 1.057 & .064 & 1 & .801 & 1.305 & .165 & 10.354 \\
\hline & Constant & $\begin{array}{l}- \\
6.733\end{array}$ & 2.058 & 10.707 & 1 & .001 & .001 & & \\
\hline
\end{tabular}
of the regression model was $5 / 10$ or equal to $50 \%$. On the other hand, 92 companies were predicted to receive nongoing concern audit opinions out of 92 companies. It could be said that the predictive power of the regression model for non-going concern audit opinion was at a perfect value of $90 / 92$ or equal to $97,8 \%$. Overall, the percentage of the predictive power of the regression model was $93.1 \%$.

Table 4. Hypothesis Test Results 
Based on testing the logistic regression equation, the following regression model is obtained:

$$
\mathrm{GC}=-6,437-0,446 \mathrm{AT}+0,043 \mathrm{AD}+26,466 \mathrm{PO}
$$

$-4,652 \mathrm{PP}+0,018$ Profit $+\varepsilon$

\section{(1) First Hypothesis Testing}

Table 4.7 shows that the audit tenure variable had a regression coefficient of -0.613 and a sig value of 0.236 . Although the direction of the regression coefficient test results was in accordance with the hypothesis, a sig value higher than 0.05 made $\mathrm{H} 1$ rejected. It denoted that the length of engagement time between the audit firm and the auditee did not affect the going concern audit opinion.

\section{(2) Second Hypothesis Testing}

The second hypothesis based on the table got a sig value of 0.028 and a regression coefficient of 0.128 . The sig value 0.128 was higher than the alpha value 0.05 , indicating that $\mathrm{H} 2$ was rejected. It signified that audit delay had no significant effect on the going concern audit opinion acceptance.

\section{(3) Third Hypothesis Testing}

The third hypothesis examined company growth's effect on the going concern audit opinion acceptance. From the test results, it was found that the sig value was 0.115 , higher than the alpha value of 0.05 , and the direction of the negative regression coefficient was with a value of -0.002 . It could be concluded that the third hypothesis was not successfully supported (H3 rejected). These results proved that company growth had no significant effect on the going concern audit opinion acceptance.

\section{(4) Fourth Hypothesis Testing}

The profitability hypothesis test results revealed the sig value of 0.009 and the regression coefficient value of -0.018 . The direction of the regression coefficient results of 0.018 was in accordance with the hypothesis's direction, which had a negative effect. Besides, the sig value of the test results was also smaller than the alpha value of 0.05 . Both made the fourth hypothesis acceptable. There was an effect of profitability on the going concern audit opinion acceptance.

\section{(5) Fifth Hypothesis Testing}

The leverage hypothesis test results showed a sig value of 0.003 and a regression coefficient of 0.002 . The direction of the regression coefficient results of 0.018 was in agreement with the hypothesis's direction, having a positive effect. Also, the sig value of the test results was smaller than the alpha value of 0.05 . These made the fifth hypothesis acceptable. It was proven that there was an effect of leverage on the acceptance of going concern audit opinion.

\section{(6) Sixth Hypothesis Testing}

The financial distress hypothesis test results showed the sig value of 0.801 and the regression coefficient value of 0.267 . The direction of the regression coefficient results of 0.267 aligned with the hypothesis's direction, which is positive. However, the sig value exceeded the alpha value of 0.05 , making the fifth hypothesis unacceptable. It was not proven that there was an effect of financial distress on the acceptance of going-concern audit opinion, so that H6 was rejected.

\section{Discussion}

\section{Audit Tenure and Going Concern}

Audit tenure is the engagement year's length between a company and an audit firm (Dewayanto [9]. The measurement counts the number of years during which the engagement occurs between the audit firm and the audited company. From the test results, it could be concluded that the audit tenure did not affect the going concern audit opinion of the auditee. It indicated that the length of time for the engagement between the audit firm and a company would not affect the auditors' performance in carrying out their duties. This study provides empirical evidence that concerns about the closeness that can reduce auditor independence because of the long engagement time between the firm and the company were not proven.

The length of time that the auditor had an engagement with a company would not reduce the auditor's vigilance and skepticism in collecting audit evidence, but on the contrary, it would make the auditor had a better understanding of the company's condition, making it easier for auditors to detect problems related to the company's survival. Besides, an engagement time limit regulated in government regulation increasingly maintained the auditors' independent attitude. Auditors in Indonesia can remain calm in maintaining their independent attitude without the need to fear losing rewards or clients. Long engagement will not reduce auditor independence. Even though there are always opportunities to commit fraud, auditors still have to work in accordance with professional ethics.

This study's results do not support the research by Krissindiastuti and Rasmini [14] and Syahputra and Yahya [6] but strengthen the research by Fahmi [48], Mariani [29], Solikhah [11], and Putri and Fettry [22]. During the audit task engagement period, auditor independence would not be easily affected. Thus, during the engagement, the auditor would not be affected by going concern audit opinion.

\section{Audit Delay and Going Concern}

Based on the test results, the second hypothesis, stating that there is a positive influence between audit delay on the acceptance of the auditee's going concern 
audit opinion, was not successfully supported (rejected). This study's results support previous research conducted by Azhar and Satriawan [1], Ibrahim and Rahardja [16], and Putri and Fettry [22] that the length of time an auditor completes an audit did not affect the acceptance of a going concern audit opinion.

On the other hand, this study does not reinforce the research results conducted by Januarti and Fitrianasari [27]. In their research, Januarti and Fitrianasari (2008) uncovered that audit delay positively affected going concern audit opinion acceptance. There was a significant relationship between audit delay and the possibility that the auditee would accept going concern audit opinion on the company's financial statements.

The auditor's length of time to complete the audit task was not caused by a problem with the auditee's financial statements. The auditing task is a task that requires accuracy and thoroughness. The auditor must be more careful and do much testing before finally giving an audit opinion. In the first and third points of the standard audit fieldwork, it is said that careful planning and sufficient evidence is needed to carry out the audit. A company to obtain a going concern audit opinion is not indicated by the longer it takes the auditor to complete the audit report.

\section{Company Growth and Going Concern}

Company growth is the increase in company revenue caused by the company's operational activities. Increasing revenue or business results from period to period can indicate that the company is experiencing growth (Nursasi and Maria, [24]. In this study, company growth was the fourth variable hypothesized to affect going concern audit opinion acceptance negatively. According to the test results, this study's fourth hypothesis could not be supported (rejected).

That study's results corroborate Mustika's [34] results, which found that company growth did not affect going concern audit opinion acceptance. According to her research, just because it had negative sales growth would not immediately make the auditor issued a going concern audit opinion. There are still many factors besides the decline in company growth that auditors consider giving a going concern opinion.

However, this study's results do not agree with Nursasi and Maria [24], who discovered that company growth had a negative effect on the going concern audit opinion acceptance.

\section{Profitability and Going Concern}

Measuring the company's ability to earn profits and assessing the efficiency level usually uses the profitability ratio (Lie, Wardani and Pikir [8]. This study's profitability ratio was measured using the return on assets (ROA), which divided the value of net profit after tax with the company's total assets. In this research, the fifth hypothesis formulated the negative effect of profitability on the going concern audit opinion acceptance. Based on the hypothesis test, it turned out that the results revealed that profitability affected the acceptance of the going-concern audit opinion.

There are many auditors' considerations before labeling the company being audited as going concern; the auditor will pay more attention to the overall economic conditions at that time and mainly focus on profitability as the dominant factor. The company will avoid the title of going concern because the financial profitability ratio of the company is high. In carrying out their audit duties, auditors certainly carry out many tests and considerations before providing an opinion. In this case, a high or low level of profitability is proven to be the dominant factor for the auditor to deliver a going concern audit opinion. Based on the results obtained, it could be inferred that the company's ability to earn profits in its operational activities guaranteed that the company would always avoid receiving a going concern audit opinion.

\section{Leverage and Going Concern}

This study proved that leverage affected the going concern audit opinion acceptance. It indicated that the higher the leverage ratio level, the higher the auditor's acceptance to provide a going concern audit opinion. This study's results verify the research conducted by Setiawan and Suryono [2]. Masyitoh and Adhariani [43] also stated that leverage was positively related to the giving of going concern audit opinion. The high leverage ratio in a company indicates unfavorable conditions because most of the funds used by the company come from debt. The high leverage ratio causes the auditors to doubt the company's going concern, thus providing a going concern audit opinion. A high leverage ratio also makes it difficult for companies to get loan funds because creditors tend to lend to companies with low leverage ratios.

\section{Financial Difficulties and Going Concern}

The sixth hypothesis state that financial difficulties affect the acceptance of going concern audit opinion. The H6 testing results obtained empirical evidence that financial condition variables did not affect going concern audit opinion acceptance. Thus, the smaller Z-Score value obtained from the bankruptcy analysis of The Altman Model (1968) indicates that companies in bad financial conditions tend not to make them a determining factor in accepting going concern audit opinion given by the auditor. However, this study is consistent with the research conducted by Azlina et al. [49], which affirmed that the financial condition variable did not affect going concern audit opinion acceptance. The effect of the variable financial condition on the going concern audit opinion acceptance is because the auditor not only considers the financial ratios in the bankruptcy analysis of The Altman Z-Score but also considers the economic conditions at that time. 


\section{CONCLUSION}

This study examined the effect of audit tenure, audit delay, company growth, profitability, leverage, and financial distress on the going concern audit opinion acceptance. Based on the analysis and testing results, it could be concluded that audit tenure, audit delay, growth, and financial difficulties did not tend to affect the acceptance of going concern audit opinion. Profitability had a negative effect, while leverage positively affected the going concern audit opinion acceptance. This study succeeded in proving that profitability and leverage variables could be an essential variable in determining going-concern opinion. Therefore, this study strengthens the findings that profitability and leverage variables are essential in future studies.

The next research is expected to sharpen these findings' analysis by expanding the business sectors, not only manufacturing. This study used the criteria that the companies had to suffer a loss after tax for at least one year. Subsequent research can tighten the criteria by increasing the percentage of loss years that the company must experience to qualify for being selected as the sample. The next study is expected to replace or add the independent variable to get better results.

\section{REFERENCES}

[1] A. Azhar, Hardi and R. R. Satriawan, "Pengaruh Audit Lag, Profitabilitas, dan Kualitas Audit terhadap Pemberian Opini Audit Going Concern pada Perusahaan Wholesale dan Retail Trade Listing di BEI Periode 2010-2012”, Jurnal Pendidikan Ekonomi dan Bisnis, Vol. 6 No 2, 2014, pp. 73-85.

[2] Setiawan, B. Suryono "Pengaruh Pertumbuhan Perusahaan, Profitabilitas, Likuiditas, dan Leverage terhadap Opini Audit Going Concern”, Jurnal Ilmu \& Riset Akuntansi, Vol. 4, No. 3, 2015, pp. 1-15.

[3] S. Mayangsari, Analisis Pengaruh Independensi, Kualitas Audit, Serta Mekanisme Corporate Governance terhadap Integritas Laporan Keuangan, Simposium Nasional Akuntansi VI, 2003, Surabaya.

[4] Kleinman, A. Anandarajan, "The Usefulness of Off-Balance Sheet Variables as Predictors of Auditors' Going Concern Opinions: An Empirical Analysis", Managerial Auditing Journal, Vol. 14 No. 6, 1999, pp. 273-285.

[5] D. Praptitorini, I. Januarti, “Analisis Pengaruh Kualitas Audit, Debt Default dan Opinion Shopping tehadap Penerimaan Opini Going Concern”, Jurnal Akuntansi dan Keuangan Indonesia, Vol. 8 No.1, 2011, pp. 78-93.
[6] Syahputra, M. R. Yahya, "Pengaruh Audit Tenure, Audit Delay, Opini Audit Tahun Sebelumnya dan Opinion Shopping terhadap Penerimaan Opini Audit Going Concern pada Perusahaan Manufaktur yang Terdaftar di Bursa Efek Indonesia Tahun 2013-2015", Jurnal Ilmiah Mahasiswa Ekonomi Akuntansi, Vol. 2 No. 3, 2017, pp. 39-47.

[7] N. Syarifah, Kurnia, "Pengaruh Faktor Keuangan dan Non Keuangan terhadap Pemberian Opini Audit Going Concern", Jurnal Ilmu dan Riset Akuntansi, Vol. 6 No. 5, 2017, pp. 2032-2050.

[8] Lie, Rr. P. Wardani and T. W. Pikir, "Pengaruh Likuiditas, Solvabilitas, Profitabilitas, dan Rencana Manajemen terhadap Opini Audit Going Concern (Studi Empiris Perusahaan Manufaktur di BEI)", Berkala Akuntansi dan Keuangan Indonesia, Vol. 1 No. 2, 2016, pp. 84-105.

[9] Wahyuni, Fitriany, Pengaruh Client Importance, Tenure, dan Spesialisasi Audit terhadap Kualitas Audit, Simposium Nasional Akuntansi XV, 2012, Banjarmasin.

[10] T. Dewayanto, "Analisis Faktor- faktor yang Mempengaruhi Penerimaan Opini Audit Going Concern pada Perusahaan Manufaktur yang Terdaftar di Bursa Efek Indonesia”, Fokus Ekonomi, Vol. 6 No 1, 2011, pp. 81-104.

[11] Solikhah, "Pertimbangan Auditor dalam Memberikan Opini Audit Going Concern”, Jurnal Ekonomi dan Keuangan, Vol. 20 No. 2, 2016, pp. 129-150.

[12] P. Rahayu, Assessing Going concern Opinion: A Study Based on Financial and Non-Financial Information, Simposium Nasional Akuntansi X, 2007, Makassar.

[13] Suwardjono, Teori Akuntansi Perekayasaan Pelaporan Keuangan, Edisi Ketiga, Yogyakarta: BPFE, 2008.

[14] Krissindiastuti, N. K. Rasmini, "Faktor-faktor yang Mempengaruhi Opini Audit Going Concern", EJurnal Akuntansi Universitas Udayana, Vol. 14, 2016, pp. 451-481.

[15] V. Carcello, Ann Vanstraelen and M. Willenborg, "Rules Rather than Discretion in Audit Standards: Going-Concern Opinions in Belgium", The Accounting Review, Vol. 84 No 5, 2009, pp. 1395 1428.

[16] S. P. Ibrahim, Raharja, "Pengaruh Audit Lag, Rasio Leverage, Rasio Arus Kas, Opini Audit Tahun Sebelumnya dan Financial Distress terhadap Penerimaan Opini Going Concern (Studi pada Perusahaan Manufaktur yang Terdaftar di BEI 
Tahun 2009-2012)", Diponegoro Journal of Accounting, Vol. 3 No. 3, 2014, pp. 1-11.

[17] H. Ashton, J. J. Willingham, and R. K. Elliott, “An Empirical Analysis of Audit Delay", Journal of Accounting Research. Vol. 25 No 2, 1987, pp. 275292.

[18] Ratmono, P. A. D. Septiana. "Dampak Konvergensi IFRS, Karakteristik Perusahaan, dan Kualitas Auditor terhadap Audit Delay", Jurnal Akuntansi dan Investasi, Vol. 16 No. 2, 2015, pp. 86-95.

[19] E. Nogler, "Long-term Effects of The Going Concern Opinion", Managerial Auditing Journal, Vol. 19, No. 5, 2004, pp. 681-688.

[20] Junaidi, J. Hartono, Faktor Non- Keuangan pada Opini Going Concern. Simposium Nasional Akuntansi XIII, 2010, Purwokerto.

[21] P. Carey, R. Simnett, "Audit Partner Tenure and Audit Quality", The Accounting Review, Vol. 81 No 3, 2006, pp. 653-676.

[22] B. Putri, S. Fettry, "Pengaruh Ukuran Perusahaan, Audit Lag, Audit Tenure, dan Opini Audit Tahun Sebelumnya terhadap Pemberian Opini Going Concern (Studi Pada Sektor Pertambangan di Bursa Efek Indonesia)", Kajian Akuntansi, Vol. 18 No. 1, 2017, pp. 46-59.

[23] N. Muttaqin, Sudarno, “Analisis Pengaruh Rasio Keuangan dan Faktor Non Keuangan terhadap Penerimaan Opini Audit Going Concern (Studi Empiris pada Perusahaan Manufaktur di BEI Tahun 2008-2010)", Diponegoro Journal of Accounting, Vol. 1, No. 2, 2012, pp. 1-13.

[24] Nursasi, E. Maria, "Pengaruh Audit Tenure, Opinion Shopping, Leverage dan Pertumbuhan Perusahaan terhadap Penerimaan Opini Audit Going Concern pada Perusahaan Perbankan dan Pembiayaan yang Go Public di Bursa Efek Indonesia", Jurnal JIBEKA, Vol. 9 No. 1, 2015, 37 43.

[25] A. Agustina, Zulaikha, "Faktor-Faktor yang Mempengaruhi Keputusan Opini Going Concern Auditor pada Perusahaan Manufaktur yang Terdaftar di Bursa Efek Indonesia (BEI)", Diponegoro Journal of Accounting, Vol. 2 No 1, 2013, pp. 1-14.

[26] A. D. Septiana, Pengaruh Penerapan IFRS, Karakteristik Perusahaan, dan Kualitas Auditor terhadap Audit Delay, Skripsi, 2015, Universitas Diponegoro. Semarang:

[27] Januarti, E. Fitrianasari, “Analisis Rasio Keuangan dan Rasio Non Keuangan yang Mempengaruhi
Auditor dalam Memberikan Opini Audit Going Concern pada Auditee (Studi Empiris pada Perusahaan Manufaktur yang Terdaftar di BEJ 2000-2005)", Jurnal MAKSI, Vol. 8 No.1, 2008, pp. 43-58.

[28] R. Astuti, Darsono, "Pengaruh Faktor Keuangan Dan Non Keuangan terhadap Penerimaan Opini Audit Going Concern", Diponegoro Journal of Accounting, Vol. 1 No 2, 2012, pp. 1-10.

[29] Mariani, "Pengaruh Audit Client Tenure, Audit Delay, Opinion Shopping, dan Proporsi Komisaris Independen terhadap Penerimaan Opini Audit Going Concern pada Perusahaan Real Estate and Property yang Terdaftar di BEI Tahun 2007-2012”, Jurnal Online Mahasiswa Fakultas Ekonomi Universitas Riau, Vol. 2 No.1, 2015, pp. 1-15.

[30] F. Sulistya, P. D. Y. Sukartha, "Pengaruh Prior Opinion, Pertumbuhan dan Mekanisme Corporate Governance pada Pemberian Opini Audit Going Concern", E-Jurnal Akuntansi Universitas Udayana, Vol. 5 No. 1, 2013, pp. 17-32.

[31] Ariesetiawan, S. Rahayu, "Pengaruh Profitabilitas, Likuiditas, dan Pertumbuhan Perusahaan terhadap Penerimaan Opini Audit Modifikasi Going Concern (Studi Pada Perusahaan Sektor Transportasi yang Terdaftar Di BEI Periode 2009-2013)", EProceeding of Management, Vol. 2 No 1, 2015, pp. 402-409.

[32] W. Aprinia, S. B. Hermanto, "Pengaruh Rasio Keuangan, Ukuran Perusahaan, dan Reputasi Auditor terhadap Opini Going Concern", Jurnal Ilmu Dan Riset Akuntansi, Vol. 5 No 9, 2016, pp. $1-20$.

[33] A. Putra, A. S. H. Anwar and T. Nur, "Pengaruh Pertumbuhan Perusahaan, Kondisi Keuangan Perusahaan, dan Opini Audit Tahun Sebelumnya terhadap Opini Audit Going Concern", Jurnal Reviu Akuntansi dan Keuangan, Vol. 6 No. 1, 2016, pp. 857-864.

[34] Mustika, "Pengaruh Kualitas Audit, Debt Default, Opinion Shopping, dan Pertumbuhan Perusahaan terhadap Penerimaan Opini Audit Going Concern pada Perusahaan Manufaktur (yang Terdaftar di Bursa Efek Indonesia 2011-2015)", JOM Fekon, Vol. 4 No. 1, 2017, pp. 1613-1627.

[35] Kartika, "Pengaruh Kondisi Keuangan dan Non Keuangan terhadap Penerimaan Opini Going Concern pada Perusahaan Manufaktur di BEI". Dinamika Akuntansi, Keuangan dan Perbankan", Vol. 1 No 1, 2012, pp. 25-40. 
[36] Kristiana, "Pengaruh Ukuran Perusahaan, Profitabilitas, Likuiditas, Pertumbuhan Perusahaan terhadap Opini Audit Going Concern pada Perusahaan Manufaktur yang Terdaftar di Bursa Efek Indonesia (BEI)", Berkala Ilmiah Mahasiswa Akuntansi, Vol 1 No. 1, 2012, pp. 47-51.

[37] Ginting, L. Suryana, “Analisis Faktor-Faktor yang Mempengaruhi Opini Audit Going Concern pada Perusahaan Manufaktur di Bursa Efek Indonesia”, Jurnal Wira Ekonomi Mikroskil, Vol. 4 No. 2, 2014, pp. 111-120.

[38] R. Sari, S. Wahyuni, "Pengaruh Kualitas Audit, Pertumbuhan Perusahaan, Likuiditas dan Solvabilitas terhadap Opini Audit Going Concern pada Perusahaan Manufaktur yang Terdaftar di BEI Periode 2011-2013", Kompartemen, Vol. 12 No. 1, 2014, pp. 69-80.

[39] S. Istiana, "Pengaruh Kualitas Audit, Opinion Shopping, Debt Default, Pertumbuhan Perusahaan dan Kondisi Keuangan Perusahaan terhadap Penerimaan Opini Audit Going Concern", Jurnal Akuntansi \& Investasi, Vol. 11 No. 1, 2010, pp. 8096.

[40] M. Pasaribu, "Pengaruh Kualitas Auditor, Likuiditas, Solvabilitas dan Profitabilitas terhadap Opini Audit Going Concern pada Sub Sektor Makanan dan Minuman yang Terdaftar di Bursa Efek Indonesia", Jurnal Riset Akuntansi dan Keuangan, Vol. 6 No. 2, 2015, pp. 80-92.

[41] V.A. Putra, E. Suryandari, “Analisis Rasio Keuangan dan Faktor Non Keuangan yang Mempengaruhi Auditor dalam Memberikan Opini Audit Going Concern pada Auditee". Jurnal Akuntansi Dan Investasi, Vol. 11 No. 1, 2010, pp. 53-67.

[42] R.A. Pradika, Sukirno. "Pengaruh Profitabilitas, Likuiditas, dan Ukuran Perusahaan terhadap Opini Audit Going Concern (Studi pada Perusahaan Manufaktur yang Terdaftar di Bursa Efek Indonesia Tahun 2012-2015)", Jurnal Profita, Vol. 5 No. 5, 2017, pp. 1-9.

[43] C. Masyitoh, D. Adhariani, The Analysis of Determinants of Going Concerm Audit Report. Journal of Modern Accounting and Auditing, Vol. 6 No. 4, 2010, pp. 26-37.

[44] Altman, T. McGough, "Evaluation of A Company as A Going Concern", Journal of Accountancy, December 1974, pp. 50-57.

[45] Mukhtaruddin, Ubaidillah, $\underline{\text { K. Dewi, and }}$ Nopriyanto, "Good Corporate Governance, Corporate Social Responsibility, Firm Value, and
Financial Performance as Moderating Variable", Indonesian Journal of Sustainability Accounting and Management, Vol. 3 No. 1, June 2019, pp.55.

[46] S.A. Ross, Fundamentals of Corporate Finance. Asia Global Edition. New York: McGraw-Hill, 2016.

[47] Rahayuningsih, "Pengaruh Kondisi Keuangan, Reputasi Auditor, Disclosure, dan Opini Audit Tahun Sebelumnya pada Pengungkapan Opini Audit Going Concern", Jurnal Akuntansi \& Auditing, Vol. 11 No. 1, 2014, pp. 25-37.

[48] N. Fahmi, "Pengaruh Audit Tenure, Opini Audit Tahun Sebelumnya, dan Disclosure terhadap Opini Audit Going Concern", Akuntabilitas, Vol. 8 No. 3, 2015, pp. 162-170.

[49] N. Azlina, E. Nur Dp, N. Ardiani, "Pengaruh Kualitas Audit, Kondisi Keuangan Perusahaan, Opini Audit Tahun Sebelumnya, Pertumbuhan Perusahaan Dan Ukuran Perusahaan Terhadap Kecenderungan Penerimaan Opini Audit Going Concern", Jurnal Ekonomi Universitas Riau, Vol. 20, No. 4 Des 201, 